\title{
Challenging complications of treatment - human herpes virus 6 encephalitis and pneumonitis in a patient undergoing autologous stem cell transplantation for relapsed Hodgkin's disease: a case report
}

\author{
Martin Bommer*1, Sandra Pauls ${ }^{2}$ and Jochen Greiner ${ }^{1}$
}

Address: ${ }^{1}$ Department of Internal Medicine III - Hematology/Oncology, University of Ulm, Ulm, Germany and ${ }^{2}$ Department of Diagnostic and Interventional Radiology, University of Ulm, Ulm, Germany

Email: Martin Bommer* - martin.bommer@uniklinik-ulm.de; Sandra Pauls - sandra.pauls@uniklinik-ulm.de;

Jochen Greiner - jochen.greiner@uniklinik-ulm.de

* Corresponding author

Published: 20 July 2009

Virology Journal 2009, 6:1II doi:10.1186/1743-422X-6-1II

This article is available from: http://www.virologyj.com/content/6/I/III

(C) 2009 Bommer et al; licensee BioMed Central Ltd.

This is an Open Access article distributed under the terms of the Creative Commons Attribution License (http://creativecommons.org/licenses/by/2.0), which permits unrestricted use, distribution, and reproduction in any medium, provided the original work is properly cited.
Received: 18 April 2009

Accepted: 20 July 2009

\begin{abstract}
Background: Reactivation of human herpesvirus 6 (HHV-6) occurs frequently in patients after allogeneic stem cell transplantation and is associated with bone-marrow suppression, enteritis, pneumonitis, pericarditis and also encephalitis. After autologous stem cell transplantation or intensive polychemotherapy HHV-6 reactivation is rarely reported.
\end{abstract}

Case report: This case demonstrates a severe symptomatic HHV-6 infection with encephalitis and pneumonitis after autologous stem cell transplantation of a patient with relapsed Hodgkin's disease.

Conclusion: Careful diagnostic work up in patients with severe complications after autologous stem cell transplantation is mandatory to identify uncommon infections.

\section{Background}

Viruses that belong to the herpes group such as HSV1/2, HHV6 and CMV are known to reactivate after intensive immunosuppressive treatment. In patients receiving allogeneic stem cell transplantation reactivations are frequently reported [1-3]. Several reports showed a broad variety of clinical manifestation, ranging from asymptomatic reactivation, delayed hematopoietic recovery up to severe systemic infection with pneumonia and encephalitis [4-8]. Reports with severe HHV6 associated complications are limited to patients receiving allogeneic transplantation or - in the autologous setting - to paediatric patients [9]. Reports of severe complications caused by HHV6 after autologous stem cell transplantation or after intensive chemotherapeutic treatments are very rare due to infrequent events, but maybe also seldom due to lack of specific diagnostic approaches.

Diagnosis of HHV6 Infection remains basically PCRbased with detection of viral DNA in blood, cerebrospinal fluid and bronchoalveolar lavage [10]. Recently evidence for integration of HHV6B-DNA in leukocytes without any clinical relevance was reported, arousing doubts about unjustified diagnosis and treatment of HHV6 infection in transplant recipients[11]. 


\section{Case presentation}

A twenty-eight years old male was admitted to our hospital with relapsed Hodgkin's disease. He had received four cycles of ABV and involved field radiation. Seven months later the lymphoma relapsed and two cycles of DexaBEAM with stem cell harvest were applied. We performed high-dose chemotherapy according to the BEAM protocol. On day twelve after stem cell reinfusion he developed mental disturbance and convulsive status. First MRI imaging of the brain showed no abnormality. Lumbar puncture was done. Cell count of the cerebrospinal fluid (CSF) was $>300 \mu \mathrm{l}$ with predominant lymphocytes. Polymerase chain reaction (PCR) test was positive for HHV6b DNA and negative for HSV 1, HSV2, EBV, CMV and enteroviridae. CT-Scan of the chest revealed diffuse bilateral interstitial pneumonia (Figure 1). Bronchoalveolar lavage was positive for HHV6b too and negative for Adenovirus, Influenza, Parainfluenza, Respiratory syncytial virus and Legionella pneumophilia. Immediate treatment with foscarnet and intravenous immunoglobulin was initiated. A second MRI of the brain two days later (Figure 2) showed diffuse inflammation compatible with herpes encephalitis. Initially the situation deteriorated due to respiratory failure and bilateral jugular vein thrombosis. Foscarnet - treatment was continued until day 44. Cerebrospinal fluid and peripheral blood were both negative for HHV6b using PCR. An oral therapy with valganciclovir was started and continued for another six weeks. The patient could be discharged from the hospital on day 48 after autologous stem cell transplantation. He recovered almost completely from his encephalitis, but unfortunately his lymphoma relapsed within nine months.

\section{Conclusion}

We report an extremely uncommon infectious complication in a patient with relapsed Hodgkin's disease. Whereas asymptomatic HHV6 reactivation is frequently reported in patients after allogeneic stem cell transplantation, severe disease is rare in patients after autologous stem cell transplantation. Nevertheless, in patients with severe complications of infections after autologous stem cell transplantation or intensive chemotherapeutic treatment, HHV-6 detection should be included into the diagnostic work-up for these patients and longitudinal observational

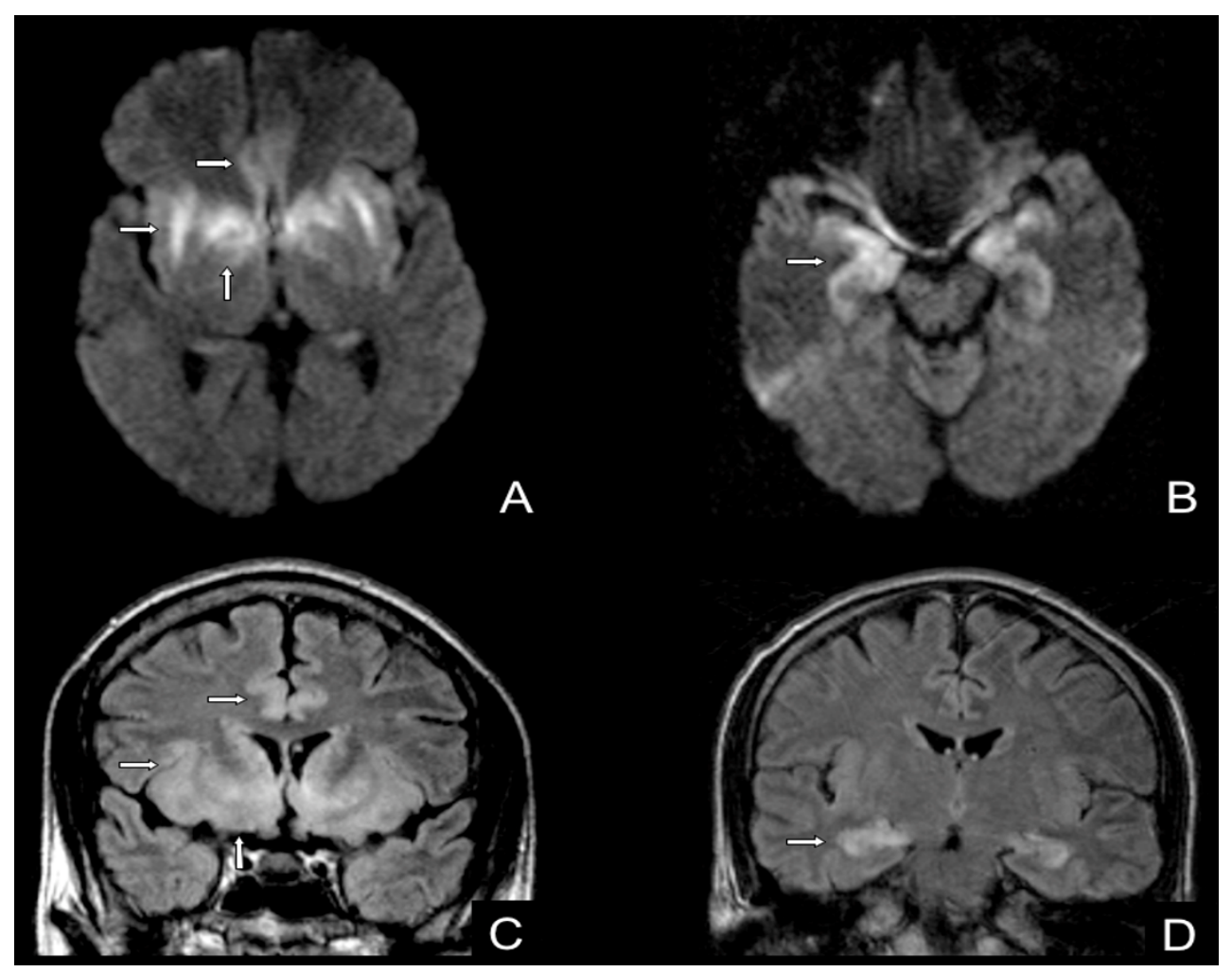

Figure I

MRI of the brain: Typically bilateral and asymmetric encephalitis of the limbic system. Diffusion weighted images (A + B; axial view): restricted diffusion (hyperintense signal) in the cingulate gyri, insula, and temporal lobes (arrows). FLAIR (C + D; coronal view) sequences: hyperintense swollen cortex and subcortical white matter (arrows) in the medial temporal lobes and cingulate gyri. 


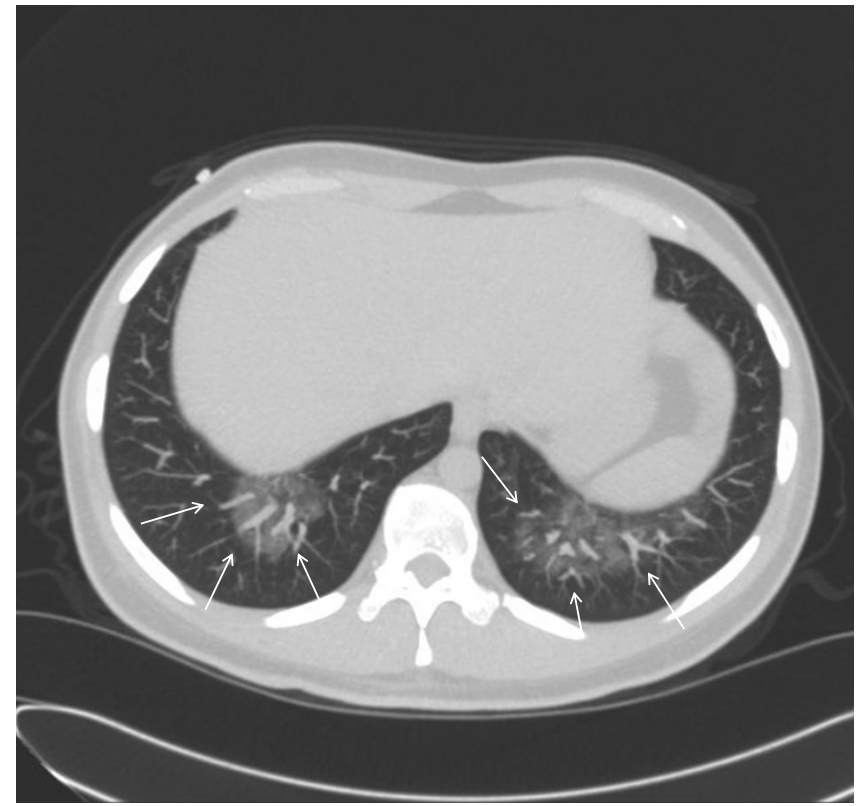

Figure 2

Chest-CT: Bilateral interstitial infiltrates.

clinical studies have to be performed to examine the frequency of clinically relevant HHV-6 infections in these patient cohorts.

\section{Consent statement}

Written informed consent was obtained from the patient for publication of this case report and accompanying images. A copy of the written consent is available for review by the Editor-in-Chief of this journal.

\section{Competing interests}

The authors declare that they have no competing interests.

\section{Authors' contributions}

GJ and BM were responsible for the patients care, PS interpreted the chest-CT and the MRI and added the figures, $\mathrm{BM}$ wrote the paper and all authors read and approved the final manuscript.

\section{Authors' information}

G.J. and B.M. are attending physicians in the department of hematology and oncology of the University of Ulm

P.S. is attending physician in the department of Diagnostic and Interventional Radiology of the University of Ulm

\section{References}

I. Ogata M, Kikuchi H, Satou T, Kawano R, lkewaki J, Kohno K, Kashima $K$, Ohtsuka E, Kadota J: Human herpesvirus 6 DNA in plasma after allogeneic stem cell transplantation: incidence and clinical significance. J Infect Dis 2006, 193:68-79.

2. Volin L, Lautenschlager I, Juvonen E, Nihtinen A, Anttila VJ, Ruutu T: Human herpesvirus 6 antigenaemia in allogeneic stem cell transplant recipients: impact on clinical course and association with other beta-herpesviruses. $\mathrm{Br} J$ Haematol 2004, 1 26:690-696.

3. Zerr DM, Corey L, Kim HW, Huang ML, Nguy L, Boeckh M: Clinical outcomes of human herpesvirus 6 reactivation after hematopoietic stem cell transplantation. Clin Infect Dis 2005, 40:932-940

4. Bissinger $\mathrm{AL}$, Einsele $\mathrm{H}$, Hamprecht $\mathrm{K}$, Schumacher $\mathrm{U}$, Kandolf $\mathrm{R}$, Loeffler J, Aepinus C, Bock T, Jahn G, Hebart H: Infectious pulmonary complications after stem cell transplantation or chemotherapy: diagnostic yield of bronchoalveolar lavage. Diagn Microbiol Infect Dis 2005, 52:275-280.

5. Fujimaki K, Mori T, Kida A, Tanaka M, Kawai N, Matsushima T, Kishi K, Fujisawa S, Sakura T, Yokota A, Kanda Y, Taguchi J, Akiyama H, Kanamori H, Maruta A, Okamoto S, Sakamaki H: Human herpesvirus 6 meningoencephalitis in allogeneic hematopoietic stem cell transplant recipients. Int J Hematol 2006, 84:432-437.

6. Gorniak RJ, Young GS, Wiese DE, Marty FM, Schwartz RB: MR imaging of human herpesvirus-6-associated encephalitis in 4 patients with anterograde amnesia after allogeneic hematopoietic stem-cell transplantation. AJNR Am J Neuroradiol 2006, 27:887-89|

7. Kim YJ, Kim DW, Lee DG, Park ST, Park YH, Min CK, Lee S, Choi JH Lee JW, Min WS, Shin WS, Kim CC: Human herpesvirus-6 as a possible cause of encephalitis and hemorrhagic cystitis after allogeneic hematopoietic stem cell transplantation. Leukemia 2002, 16:958-959.

8. Vu T, Carrum G, Hutton G, Heslop HE, Brenner MK, Kamble R: Human herpesvirus-6 encephalitis following allogeneic hematopoietic stem cell transplantation. Bone Marrow Transplant 2007, 39:705-709.

9. Savolainen H, Lautenschlager I, Piiparinen H, Saarinen-Pihkala U, Hovi L, Vettenranta K: Human herpesvirus- 6 and $\mathbf{- 7}$ in pediatric stem cell transplantation. Pediatr Blood Cancer 2005, 45:820-825.

10. Allen UD, Tellier R, Doyle J, Petric M, Wasfy S, Kumar P, Calderwood $S$, Freedman M, Saunders F: The utility of plasma polymerase chain reaction for human herpes virus- 6 among pediatric bone marrow transplant recipients: results of a pilot study. Bone Marrow Transplant 200I, 28:473-477.

II. Kamble RT, Clark DA, Leong HN, Heslop HE, Brenner MK, Carrum $G$ : Transmission of integrated human herpesvirus- 6 in allogeneic hematopoietic stem cell transplantation. Bone Marrow Transplant 2007, 40:563-566.
Publish with Bio Med Central and every scientist can read your work free of charge

"BioMed Central will be the most significant development for disseminating the results of biomedical research in our lifetime. "

Sir Paul Nurse, Cancer Research UK

Your research papers will be:

- available free of charge to the entire biomedical community

- peer reviewed and published immediately upon acceptance

- cited in PubMed and archived on PubMed Central

- yours - you keep the copyright
BioMedcentral 